\title{
Weed Control in Soybean Cultivated in Minimum Tillage System and the Production Obtained at Ards Turda
}

\author{
Cornel CHEŢAN $^{1,2}$, Teodor RUSU ${ }^{2}$, Ileana BOGDAN ${ }^{2}$, Felicia CHEȚAN $^{1,2}$, Alina ŞIMON ${ }^{1,2}$ \\ ${ }^{1}$ Agricultural Research and Development Station, Turda, 27 Agriculturii Street, Cluj County, Romania, \\ Email:cornel_chetan@yahoo.com \\ ${ }^{2}$ University of Agricultural Sciences and Veterinary Medicine Cluj-Napoca, 3-5, Manastur Street, \\ 400372, Romania, Email: trusu@usamvcluj.ro
}

Bulletin USAMV serie Agriculture 71(1-2)/2014

Print ISSN 1843-5246; Electronic ISSN 1843-5386

DOI: $10.15835 /$ buasvmcn-agr: 10217

\begin{abstract}
The use of herbicides determine productivity growth, but the herbicides are produced by synthesis, out of ecosystem. Misused of herbicides, after a thorough knowledge, they can become dangerous for the environment through the introduction of toxic residues in agricultural ecosystems. Is necessary to reduce utilized doses, to use of conservative technologies, but also is necessary some alternative solutions to build, effective weed control in new conditions. Changing the soil work system and using the soil minimum tillage system, like a conservative option, change the weed spectrum in soybean culture. Soybean is more sensitive to imbue culture with weed; especially in the first 25 days of the vegetation period, when the plants are grows, and the soybean plants remain undeveloped. Further fill with weeds of the culture diminishes production and the quality of the seeds. The researches at ARDS Turda in the agricultural year 2012-2013 aimed to the effect of 12 types of herbicides in soybean crop grown in two systems of soil work: classical system and minimum tillage system. Experience are made on a clayey - loam soil, bi-factorial experience type being, with variants specific soybean culture, with combination of herbicides and with different moments of application. Soybean yield is not influenced significantly of soil system of work, but productions are influenced distinctly significant or very significant of treatment variant of weed control. In the minimum tillage system fill with weeds of soybean culture are higher in comparison with classical system of soil work. This is due to the work the soil in the autumn, when it is fall plowed, and the lack of rain in spring. The system work of soil, are influence upon the spectrum of weeds and the combination of herbicides used, for an sensitive culture like soybean, may be established on complementarity by scientific considerations.
\end{abstract}

Keywords: minimum tillage, weeds control, yield, clime conditions

\section{INTRODUCTION}

Minimum tillage (MT) system of seeding, was, at firs an a efficient technology for soil conservation against the erosion of soil. Over time it evolved toward an economic system of agriculture, as an alternative to the conventional system (CS). The results of this system of soil work is improved physical properties, chemical and biological properties of the soil, reduces the risk of environmental pollution by reducing losses of nutrients and direct or indirect loss of emissions of greenhouse gases. The minimum tillage systems of soil work, if they are applied accordingly, also aimed at reducing erosion and soil compaction, reducing energy consumption, plant protection, soil and water conservation and fuel economy (Fabrizzi et al., 2005; Moraru et al., 2010; Bucur et al., 2011; Rusu et al., 2014).

The most valuable oleo-protein plant, cultivation in many countries of world, is used for biomass, and seeds who have high quantity of proteins, fats, vitamins and minerals (Muntean et al., 1995; Scurtu, 2001; Gus et al., 2004). To obtain some high production and a high quality of seeds, a special role, along with other technological links and biological material, it has weed control (Ionescu, 2000). Roots of soybean (about 75\%) developed in level of $30 \mathrm{~cm}$ from soil surface, 
and precipitation have a decisive role in realized of soybean yield and weeds control (Rusu, 2001; Gus et al., 2004). Soybean can easy cultivate in MT system. Production results obtained are approximately equal to those obtained in the CS system.

Treatments with herbicides applied to the soil at the same time with preparation of the soil and with treatments in vegetation ensure free weed productions if the species of weeds are known in all stages of development of the soybean (Berca, 2004; Rusu, 2012). Production losses due to weeds infection may up to $80 \%$ (Scurtu, 2001). In this situation technical and chemical means are needed for weed control and realized a grown yield.

The aims of researches present in this paper are the influence of treatments and the effectiveness of herbicides utilize in weed control in relation to the work of the soil and their influence on the degree weeds and the product obtained.

\section{MATERIAL AND METHODS}

The researches were conducted in 2012-2013 culturalyear atARDS Turda, located in Transylvania Plain, a soil type vertic phaeozem with a clay loam texture, with a neutral $\mathrm{pH}$, with a very good supply of mobile phosphorus and potassium and with a medium quantity of humus. This experience have two factors: AxB-R:2x12-3, organized in latin rectangle method. Biological material used in the experiment was Felix soybean variety (maturity group 00, period of vegetation: 122 day). Felix soybean variety was created at ARDS Turda; it is a variety with high class suitable for mechanized harvesting, with a height of insertion of the basal pods of $16 \mathrm{~cm}$ and with very good resistance to diseases and pests.

Experimental factors are:

A - System of soil work with two variants: $A_{1}-$ conventional system with plowing (CS): plowing + soil preparation with rotary harrow + seeding + fertilization; $\mathrm{A}_{2}-$ minimum tillage system (MT): preparation soil with chisel + work with

Tab. 1. The scheme of treatments

\begin{tabular}{|c|c|c|c|}
\hline $\begin{array}{l}\text { Vari- } \\
\text { ant }\end{array}$ & Herbicide use & Rates l, g/ha & $\begin{array}{l}\text { Time of } \\
\text { aplication }\end{array}$ \\
\hline $\mathrm{B}_{1}$ & Untreated & - & - \\
\hline $\mathrm{B}_{2}$ & $\begin{array}{l}\text { Dual Gold } 960 \text { EC (S-metolaclor } 960 \text { g/l) } \\
\text { Pulsar } 40 \text { (Imazamox } 40 \text { g/l) + Agil } 100 \text { EC (Propaquizafop } 100 \text { g/l) }\end{array}$ & $\begin{array}{c}\text { 1,5 l/ha } \\
0,8 \mathrm{l} / \mathrm{ha}+1,5 \mathrm{l} / \mathrm{ha}\end{array}$ & $\begin{array}{c}\text { ppi } \\
\text { post I }\end{array}$ \\
\hline $\mathrm{B}_{3}$ & $\begin{array}{l}\text { Frontier Forte (Dimetenamid } 720 \mathrm{~g} / \mathrm{l} \text { ) } \\
\text { Basagran Forte (Bentazon } 480 \mathrm{~g} / \mathrm{l} \text { ) + Fusilade Forte (Fluazifop-P-butil } 150 \\
\mathrm{~g} / \mathrm{l} \text { ) }\end{array}$ & $\begin{array}{c}1,2 \mathrm{l} / \mathrm{ha} \\
2,5 \mathrm{l} / \mathrm{ha}+1,5 \mathrm{l} / \mathrm{ha}\end{array}$ & $\begin{array}{c}\text { ppi } \\
\text { post I }\end{array}$ \\
\hline $\mathrm{B}_{4}$ & $\begin{array}{l}\text { Proponit } 720 \text { EC (Propisoclor } 720 \mathrm{~g} / \mathrm{l} \text { ) } \\
\text { Pulsar } 40 \text { (Imazamox } 40 \mathrm{~g} / \mathrm{l} \text { ) +Leopard } 5 \text { EC (Quizalofop-P-etil } 50 \mathrm{~g} / \mathrm{l} \text { ) }\end{array}$ & $\begin{array}{c}3,0 \mathrm{l} / \mathrm{ha} \\
1,0 \mathrm{l} / \mathrm{ha}+2,0 \mathrm{l} / \mathrm{ha}\end{array}$ & $\begin{array}{c}\text { ppi } \\
\text { post I }\end{array}$ \\
\hline $\mathrm{B}_{5}$ & $\begin{array}{l}\text { Stomp } 330 \text { EC (Pendimetalin } 330 \mathrm{~g} / \mathrm{l}) \\
\text { Pulsar } 40 \text { (Imazamox } 40 \mathrm{~g} / \mathrm{l})+ \text { Select Super (Cletodim } 120 \mathrm{~g} / \mathrm{l})\end{array}$ & $\begin{array}{c}5,0 \mathrm{l} / \mathrm{ha} \\
1,0 \mathrm{l} / \mathrm{ha}+2,0 \mathrm{l} / \mathrm{ha}\end{array}$ & $\begin{array}{c}\text { ppi } \\
\text { post I }\end{array}$ \\
\hline $\mathrm{B}_{6}$ & $\begin{array}{l}\text { Sencor } 70 \text { WG (Metribuzin } 700 \text { g/kg) } \\
\text { Basagran Forte (Bentazon } 480 \mathrm{~g} / \mathrm{l} \text { ) + Agil (Propaquizafop } 100 \mathrm{~g} / \mathrm{l} \text { ) }\end{array}$ & $\begin{array}{c}0,4 \mathrm{~kg} / \mathrm{ha} \\
2,5 \mathrm{l} / \mathrm{ha}+1,0 \mathrm{l} / \mathrm{ha}\end{array}$ & $\begin{array}{c}\text { ppi } \\
\text { post I }\end{array}$ \\
\hline $\mathrm{B}_{7}$ & $\begin{array}{l}\text { Guardian (Acetoclor } 820 \mathrm{~g} / \mathrm{l})+ \text { Sencor } 70 \text { WG (Metribuzin } 700 \mathrm{~g} / \mathrm{kg} \text { ) } \\
\text { Pulsar } 40 \text { (Imazamox } 40 \mathrm{~g} / \mathrm{l} \text { ) + Fusilade Forte (Fluazifop-P-butil 150 g/l) }\end{array}$ & $\begin{array}{l}2,2 \mathrm{l} / \mathrm{ha}+0,4 \mathrm{~kg} / \mathrm{ha} \\
1,2 \mathrm{l} / \mathrm{ha}+1,5 \mathrm{l} / \mathrm{ha}\end{array}$ & $\begin{array}{l}\text { preem } \\
\text { post I }\end{array}$ \\
\hline $\mathrm{B}_{8}$ & $\begin{array}{l}\text { Dual Gold } 960 \text { EC (S-metolaclor } 960 \mathrm{~g} / \mathrm{l})+ \text { Sencor WG (Metribuzin } 700 \mathrm{~g} / \mathrm{kg} \text { ) } \\
\text { Basagran Forte (Bentazon } 480 \mathrm{~g} / \mathrm{l})+ \text { Leopard } 5 \mathrm{EC} \text { (Quizalofop-P-etil } 50 \mathrm{~g} / \mathrm{l} \text { ) } \\
\text { Basagran Forte (Bentazon } 480 \mathrm{~g} / \mathrm{l})\end{array}$ & $\begin{array}{c}1,4 \mathrm{l} / \mathrm{ha}+0,4 \mathrm{l} / \mathrm{ha} \\
1,2 \mathrm{l} / \mathrm{ha}+1,0 \mathrm{l} / \mathrm{ha} \\
1,0 \mathrm{l} / \mathrm{ha}\end{array}$ & $\begin{array}{l}\text { preem } \\
\text { post I } \\
\text { post II }\end{array}$ \\
\hline $\mathrm{B}_{9}$ & $\begin{array}{l}\text { Frontier Forte (Dimetenamid 720 g/l) + Sencor 70 WG (Metribuzin 700 g/kg) } \\
\text { Pulsar } 40 \text { (Imazamox } 40 \mathrm{~g} / \mathrm{l})+ \text { Agil (Propaquizafop } 100 \mathrm{~g} / \mathrm{l}) \\
\text { Pulsar } 40 \text { (Imazamox } 40 \mathrm{~g} / \mathrm{l})\end{array}$ & $\begin{array}{l}2,5 \mathrm{l} / \mathrm{ha}+2,5 \mathrm{l} / \mathrm{ha} \\
3,0 \mathrm{l} / \mathrm{ha}+1,5 \mathrm{l} / \mathrm{ha} \\
1,0 \mathrm{l} / \mathrm{ha}\end{array}$ & $\begin{array}{l}\text { preem } \\
\text { post I } \\
\text { post II }\end{array}$ \\
\hline $\mathrm{B}_{10}$ & $\begin{array}{l}\text { Proponit } 720 \text { EC (Propisoclor } 720 \mathrm{~g} / \mathrm{l} \text { ) + Sencor } 70 \mathrm{WG} \text { (Metribuzin } 700 \mathrm{~g} / \mathrm{kg} \text { ) } \\
\text { Basagran Forte (Bentazon } 480 \mathrm{~g} / \mathrm{l} \text { ) + Select Super (Cletodim } 120 \mathrm{~g} / \mathrm{l} \text { ) }\end{array}$ & $\begin{array}{l}\text { 2,5l/ha+0,4l/ha } \\
3,0 \mathrm{l} / \mathrm{ha}+1,5 \mathrm{l} / \mathrm{ha}\end{array}$ & $\begin{array}{l}\text { preem } \\
\text { post I }\end{array}$ \\
\hline $\mathrm{B}_{11}$ & $\begin{array}{l}\text { Stomp } 330 \text { EC (Pendimetalin } 330 \mathrm{~g} / \mathrm{l} \text { ) + Sencor } 70 \mathrm{WG} \text { (Metribuzin } 700 \mathrm{~g} / \mathrm{kg} \text { ) } \\
\text { Harmony } 50 \text { SG (Tifensulfuron-metil 50\%) + Agil (Propaquizafop } 100 \mathrm{~g} / \mathrm{l} \text { ) } \\
\text { Harmony } 50 \text { SG (Tifensulfuron-metil 50\%) }\end{array}$ & $\begin{array}{c}4 \mathrm{l} / \mathrm{ha}+0,4 \mathrm{l} / \mathrm{ha} \\
12 \mathrm{~g} / \mathrm{ha}+1,5 \mathrm{l} / \mathrm{ha} \\
12 \mathrm{~g} / \mathrm{ha}\end{array}$ & $\begin{array}{l}\text { preem } \\
\text { post I } \\
\text { post II }\end{array}$ \\
\hline $\mathrm{B}_{12}$ & $\begin{array}{l}\text { Sencor } 70 \text { WG (Metribuzin } 700 \mathrm{~g} / \mathrm{kg} \text { ) } \\
\text { Harmony } 50 \text { SG (Tifensulfuron-metil 50\%) + Select Super (Cletodim } 120 \mathrm{~g} / \mathrm{l} \text { ) }\end{array}$ & $\begin{array}{c}0,5 \mathrm{l} / \mathrm{ha} \\
18 \mathrm{~g} / \mathrm{ha}+2,0 \mathrm{l} / \mathrm{ha}\end{array}$ & $\begin{array}{l}\text { preem } \\
\text { post I }\end{array}$ \\
\hline
\end{tabular}


rotary harrow + seeding and fertilizing same time. Mineral fertilization dose was $100 \mathrm{~kg} /$ ha (NPK 20:20:0). Seeding was executed with seeding machine Gaspardo Directa - 400 and with John Deere 6630 SE, tractor, at $18 \mathrm{~cm}$ distance between rows, deep of seeding $5 \mathrm{~cm}$; the norm of seeding $119 \mathrm{~kg} / \mathrm{ha}$.

$B$ - Herbicides variation: $B_{1}$ - untreated; $B_{2}-B_{12}$ - different doses of herbicides, different combination of herbicides and different moments of application. Treatments scheme and doses applied are represented in table 1.

The experimental plots size is $48 \mathrm{~m}^{2}$. Upcoming plant soybean crop was maize. Determination of weed's degree was made with metric frame utilized the gravitational-quantitative method, determination of the quantity of crop was evaluation in every plot, and statistical processing of the results utilized variances analysis.

Pre-sowing turned under soil at 2-6 variants was applied before seeding the soybean culture, but in 7-12 variants was applied immediately after sowing soybean, but before it rising. Completion of pre-emerging treatments with post-emerging treatments on vegetation when the soybean yield have 4-6 leaf and dicotyledonous weeds are in rosette stage and monocotyledonous weeds have $15-20 \mathrm{~cm}$ highest. The last treatment in postemerging was applied in 8-9-11 variants, when soybean and weeds there are in a more advanced growth stage. For strong results was taken some combination of herbicides with complementary action.

\section{RESULTS AND DISCUSSION}

The soybean tilled in conditions of Transylvanian Plain are heavily plain of weeds if preventive measures are not taken by an differentiated agrotechnical curative measures and correct items. Climatic conditions are a high influence in covered with weeds of the plots.

The weeds species existing in minimum tillage experiences it was result 21 species, the more common are: Xantium strumarium and Hibiscus trionum (participation of 21-100\%), in second places are yearly monocotyledonous Setaria glauca and Echinocloua crus-galli (participation of $8-80 \%)$. The species perennial dicotyledonous plants participated in weeding level with values ranging between 3 to $40 \%$ and perennial monocotyledonous species of Agropyron repens represented only some variations but the percentage of $13-77 \%$ (hearths).

In the variants with soybean cultivated in classical system was attended by a total of 24 species of weeds, weeds annual dicotyledonous plants being present in all the experimental variants with participation from 1-100\%. Xanthium strumarium represented the most common species, the presence of which is between 55-123 plants $\backslash$ / $\mathrm{m} 2$. Weeds perennial dicotyledonous plants had a percentage of participation in the weeding $2-21 \%$, the highest proportion having regard to Convolvulus arvensis (4-21\%) its presence is recorded in all variations. Monocotyledonous annual weeds (with participation of 1-26\%) occur in later culture and no longer cause major damage to culture. Through the work of plowing with the plough in autumn (with tiling return) combat largely Agropyron repens, the result being the low participation rate of $3-9 \%$ in the three experimental variations compared to the high percentage of $13-77 \%$ of the experience with minimal work.

Hot springs in the degree of weeding of the soybean crop is larger, this being due to their capacity of adaptation to the harsh environmental conditions of cultivated plant. Due to the lack of water in the soil both before sowing and after sowing soybean seed had a poor outcome of germination is appearance flawed, the land has been invaded by weeds that competed heavily soy plants. The rains came after a long and rather weak quantitatively determined the appearance soy plants staggered, so that from the date of sowing (April 2013) and up to appearance of culture (end of May) has gone nearly a month, during which time weeds have occupied the land and applied pre-emergent ground has not had the desired effect.

In table 2 and table 3 temperatures and rainfall recorded during the period 1 April-30 September 2013, compared with the average over the last 55 years. The months of April and may were warm with little rain Monday; June one month, normal in terms of precipitation; July and excessively dry with $37.6 \mathrm{~mm}$ multiannual average that is 76.7 $\mathrm{mm}$. The average temperature of $22.1^{\circ} \mathrm{C}$ and 44 $\mathrm{mm}$ august rainfall is characterized as being warm and dry. October has seen temperatures of $13.8^{\circ} \mathrm{C}$ and $57.8 \mathrm{~mm}$ and rainfall on average 55 years $\left(14.9^{\circ} \mathrm{C}, 40.3 \mathrm{~mm}\right)$, which characterized him as cool and very rainy month. 
Soybean requirements for humidity are high, with the critical period in second decade of June and mid-august, during blooming and seed filling. As shown in table 2, during periods covered by the amount of precipitation was less than average for the past 50 years what took aim on the growth and development of plants, size and weight of the seed with negative effect on production. The temperatures recorded in flowering and fructification period of soybean seeds (reproductive phase) were between 19$22^{\circ} \mathrm{C}$, table 3 , hovering in the range of soybean in relation to temperature requirements $\left(20-22^{\circ} \mathrm{C}\right)$.

Tab. 2. Precipitation regime at ARDA Turda in the period 1 April-30 September 2013

\begin{tabular}{|c|c|c|c|c|c|}
\hline \multirow{2}{*}{ Month } & \multicolumn{3}{|c|}{ Precipitation, $\mathrm{mm}$} & \multirow{2}{*}{$\begin{array}{c}\text { Average from month } \\
\mathrm{mm}\end{array}$} & \multirow{2}{*}{$\begin{array}{c}\text { Average from } 55 \text { years } \\
\mathrm{mm}\end{array}$} \\
\hline & Decade I & Decade II & Decade III & & \\
\hline IV & 43.9 & 8.6 & 0.8 & 53.3 & 44.7 \\
\hline $\mathrm{V}$ & 1.5 & 24.2 & 53.6 & 79.3 & 67.7 \\
\hline $\mathrm{VI}$ & 45.6 & 14.2 & 26.4 & 86.2 & 84.5 \\
\hline VII & 27.0 & 8.4 & 2.2 & 37.6 & 76.7 \\
\hline VIII & 0.6 & 7.8 & 35.6 & 44.0 & 55.9 \\
\hline IX & 5.0 & 28.6 & 24.2 & 57.8 & 40.3 \\
\hline
\end{tabular}

Tab. 3. Thermal regime at ARDS Turda in the period 1 April - 30 September 2013

\begin{tabular}{cccccc}
\hline \multirow{2}{*}{ Month } & \multicolumn{3}{c}{ Temperature, ${ }^{\circ} \mathrm{C}$} & Average from month & Average from 55 years \\
\cline { 2 - 6 } & Decade I & Decade II & Decade III & ${ }^{\circ} \mathrm{C}$ & ${ }^{\circ} \mathrm{C}$ \\
\hline IV & 7.4 & 11.6 & 17.8 & 12.3 & 9.8 \\
\hline V & 20.3 & 16.5 & 14.0 & 16.8 & 14.7 \\
\hline VI & 16.0 & 22.3 & 19.9 & 19.4 & 17.7 \\
\hline VII & 20.2 & 19.5 & 22.7 & 20.9 & 19.6 \\
\hline VIII & 25.2 & 22.3 & 19.0 & 22.1 & 19.2 \\
\hline IX & 16.3 & 13.6 & 11.5 & 13.8 & 14.9 \\
\hline
\end{tabular}

Tab. 4. The influence of the work of the soil and of the herbicide weed variant dicotyledonous plants, cultivated soybean , ARDS Turda, 2013

\begin{tabular}{|c|c|c|c|c|c|c|c|c|c|c|c|c|}
\hline \multirow{3}{*}{ Variant } & \multicolumn{6}{|c|}{ Weeds annual dicotyledonous } & \multicolumn{6}{|c|}{ Weeds perennial dicotyledonous } \\
\hline & \multicolumn{2}{|c|}{ Nr. weeds, } & \multicolumn{2}{|c|}{$\begin{array}{c}\text { Average } \\
\text { weight } \mathrm{g} / \mathrm{m}^{2}\end{array}$} & \multicolumn{2}{|c|}{$\begin{array}{l}\text { The mass of } \\
\text { weeds, } t / \text { ha }\end{array}$} & \multicolumn{2}{|c|}{ Nr. weeds, } & \multicolumn{2}{|c|}{$\begin{array}{c}\text { Average } \\
\text { weight, } \mathrm{g} / \mathrm{m}^{2}\end{array}$} & \multicolumn{2}{|c|}{$\begin{array}{l}\text { The mass of } \\
\text { weeds, } t / h a\end{array}$} \\
\hline & $\mathrm{CS}$ & MT & $\mathrm{CS}$ & MT & $\mathrm{CS}$ & MT & $\mathrm{CS}$ & MT & $\mathrm{CS}$ & MT & $\mathrm{CS}$ & MT \\
\hline $\mathrm{B}_{1}$ & 5.75 & 31 & 403 & 1505 & 4.0 & 15.1 & 0.75 & - & 10.2 & - & 0.1 & - \\
\hline $\mathrm{B}_{2}$ & 4 & 18.75 & 179.7 & 777.8 & 1.8 & 7.8 & - & - & - & - & - & - \\
\hline $\mathrm{B}_{3}$ & 6 & 10.25 & 642.8 & 890.7 & 6.4 & 8.9 & 0.5 & - & 14.5 & - & 0.1 & - \\
\hline $\mathrm{B}_{4}$ & 2.75 & 12 & 229.3 & 743.8 & 2.3 & 7.4 & - & 1.25 & - & 125.4 & - & 1.3 \\
\hline $\mathrm{B}_{5}$ & 9 & 14.25 & 164.6 & 242.5 & 1.6 & 2.4 & 1.75 & - & 20.3 & - & 0.2 & - \\
\hline $\mathrm{B}_{6}$ & 2 & 6.25 & 303.4 & 175.7 & 3.0 & 1.8 & - & 0.25 & - & 19.5 & - & 0.2 \\
\hline $\mathrm{B}_{7}$ & 3 & 3.25 & 174.3 & 332.1 & 1.7 & $\begin{array}{l}3.3 \\
\end{array}$ & 0.25 & - & 7.1 & - & 0.07 & - \\
\hline $\mathrm{B}_{8}$ & 2.5 & 2 & 480.2 & 306.2 & 4.8 & 3.1 & - & - & - & - & - & - \\
\hline $\mathrm{B}_{9}$ & 3.5 & 2.25 & 84.3 & 681.8 & 0.8 & 6.8 & - & - & - & - & - & - \\
\hline $\mathrm{B}_{10}$ & 3 & 3.25 & 345.5 & 461.3 & 3.5 & 4.6 & 0.5 & - & 28.9 & - & 0.3 & - \\
\hline $\mathrm{B}_{11}$ & 4 & 13.5 & 296.2 & 596.1 & 3.0 & 6.0 & - & - & - & - & - & - \\
\hline$B_{12}$ & 3.25 & 5.25 & 384.5 & 449.2 & 3.8 & 4.5 & - & - & - & - & - & - \\
\hline
\end{tabular}


WeedingwithXanthiumstrumarium hasbecome an issue because appearances had a long period so that after applying the herbicide on vegetation new plantlets were able to infesteze again, this culture as literature derives from the ability of the grain to remain viable for up to 6 years. Due to the staggered weed appearance, new treatments are necessary combinations of herbicides pre-emergent with differentiated application: before sowing, immediately after sowing before appearance soy culture and vegetation to capture the optimal time to control weeds. Soybean crop is infested with many species of weeds in greater quantities being dicotiledonatele (table 4), and monocotiledonatele (table 5), weeding and determine the influence of soy production. Due to the dense sowing soybean lines (at 18 inches between rows) weed control through mechanical or manual diggers is not running, so the profitability of culture lies in the effectiveness of herbicide use (chemical control).

The soybeans grown in the classical system (table 6) formation was found a mass of weeds from between $1.77 \mathrm{t} / \mathrm{ha}\left(\mathrm{B}_{7}\right.$ with the herbicid Guardian pre-emergent application (acetogan), Sencor postemergentI and Pulsar \& Fusilade) 4.62 and t/ha ( $B_{1}$ untreated). Of all weeds of $42.5 \mathrm{t} / \mathrm{ha}$, quantitatively dominated the annual dicotyledonous (DA) with
$36.7 \mathrm{t} /$ ha of $86.35 \%$ of the total, followed by the annual monocotyledonouos (MA) with $4.9 \mathrm{t} / \mathrm{ha}$ of $11.53 \%$. Infestation with perennial dicotyledonous plants (DP) was $1.81 \%$ of the total with a $0.77 \mathrm{t} /$ ha and perennial monocotyledonous (MP) $0.31 \%$ percent with $0.13 \mathrm{t} / \mathrm{ha}$. The cultivation of soybean in minimum tillage system, the total mass of weeds was $81.02 \mathrm{t} / \mathrm{ha}$ of which $71.7 \mathrm{t} / \mathrm{ha}(88.50 \%) \mathrm{DA}$ weed; 1.5 t/ha DP (1.5\%), 7.8 t/ha MA (7.8\%); $0.02 \mathrm{t} / \mathrm{ha}$ MP $(0.02 \%)$. In both systems work of the soil quantitatively dominated the weeds DA and MA.

The production of soybeans is not significantly influenced by the work of the soil (table 7), but is influenced differently (distinct ample and very significant) of the chosen for weed control (table $8)$.

Bifactorial analysis of the interaction of variants are factors, soil tillage system $\mathrm{x}$ variant of herbicides (table 9) reveals the importance of the choice of herbicid records in relation to the work of the soil. This is because the soil influences the work spectrum of weeds, the combination of herbicide used, for a culture-sensitive as soybeans, must be determined on the basis of complementarity scientific.

Tab. 5. The influence of the work of the soil and of the herbicide weed variant monocotyledonous, in soybean culture, ARDS Turda, 2013

\begin{tabular}{|c|c|c|c|c|c|c|c|c|c|c|c|c|}
\hline \multirow{3}{*}{ Variant } & \multicolumn{6}{|c|}{ Monocotyledonous annual weeds } & \multicolumn{6}{|c|}{ Monocotyledonous perennial weeds } \\
\hline & \multicolumn{2}{|c|}{ Nr. weeds, } & \multicolumn{2}{|c|}{$\begin{array}{c}\text { Average } \\
\text { weight, } \mathrm{g} / \mathrm{m}^{2}\end{array}$} & \multicolumn{2}{|c|}{$\begin{array}{l}\text { The mass of } \\
\text { weeds, } t / \text { ha }\end{array}$} & \multicolumn{2}{|c|}{ Nr.weeds, } & \multicolumn{2}{|c|}{$\begin{array}{c}\text { Average } \\
\text { weight, g/ } \\
\mathrm{m}^{2}\end{array}$} & \multicolumn{2}{|c|}{$\begin{array}{l}\text { The mass of } \\
\text { weeds, } t / \text { ha }\end{array}$} \\
\hline & $\mathrm{CS}$ & MT & $\mathrm{CS}$ & MT & $\mathrm{CS}$ & MT & $\mathrm{CS}$ & MT & $\mathrm{CS}$ & MT & $\mathrm{CS}$ & MT \\
\hline $\mathrm{B}_{1}$ & 2.25 & 5.5 & 46.1 & 393.5 & 0.5 & 3.9 & 0.25 & - & 2.1 & - & 0.02 & - \\
\hline $\mathrm{B}_{2}$ & 0.5 & 4 & 55.6 & 24.9 & 0.6 & 0.2 & - & - & - & - & - & - \\
\hline $\mathrm{B}_{3}$ & 0.5 & 0.25 & 67.2 & 7.9 & 0.7 & 0.08 & 1.25 & - & 6.9 & - & 0.07 & - \\
\hline $\mathrm{B}_{4}$ & 0.5 & 0.5 & 80.1 & 58.4 & 0.8 & 0.6 & - & - & - & - & - & - \\
\hline $\mathrm{B}_{5}$ & - & 0.25 & - & 13.5 & - & 0.1 & - & - & - & - & - & - \\
\hline $\mathrm{B}_{6}$ & 0.5 & - & 69.3 & - & 0.7 & - & - & - & - & - & - & - \\
\hline $\mathrm{B}_{7}$ & - & 2.5 & - & 118 & - & 1.2 & - & - & - & - & - & - \\
\hline $\mathrm{B}_{8}$ & - & 2 & - & 152.9 & - & 1.5 & - & - & - & - & - & - \\
\hline $\mathrm{B}_{9}$ & 0.25 & 1 & 32.2 & 16.7 & 0.3 & 0.2 & 0.25 & - & 4.1 & - & 0.04 & - \\
\hline $\mathrm{B}_{10}$ & 0.5 & - & 59.8 & - & 0.6 & - & - & - & - & - & - & - \\
\hline $\mathrm{B}_{11}$ & 0.75 & - & 42.6 & - & 0.4 & - & - & 0.25 & - & 2.1 & - & 0.02 \\
\hline $\mathrm{B}_{12}$ & 0.25 & - & 29.9 & - & 0.3 & - & - & - & - & - & - & - \\
\hline
\end{tabular}


Tab. 6. The influence of the work of the soil and of the herbicide, which has a total weight of weeds in soybean culture, ARDS Turda, 2013

\begin{tabular}{|c|c|c|c|c|c|c|c|c|c|c|}
\hline \multirow{4}{*}{ Variant } & \multicolumn{10}{|c|}{ The mass of weeds, $t / h a$} \\
\hline & \multirow{2}{*}{\multicolumn{2}{|c|}{ Total }} & \multicolumn{8}{|c|}{ of which: } \\
\hline & & & \multicolumn{2}{|c|}{ DA } & \multicolumn{2}{|c|}{ DP } & \multicolumn{2}{|c|}{ MA } & \multicolumn{2}{|c|}{ MP } \\
\hline & $\mathrm{CS}$ & MT & $\mathrm{CS}$ & MT & $\mathrm{CS}$ & MT & $\mathrm{CS}$ & MT & $\mathrm{CS}$ & MT \\
\hline $\mathrm{B}_{1}$ & 4.62 & 19 & 4.0 & 15.1 & 0.1 & - & 0.5 & 3.9 & 0.02 & - \\
\hline $\mathrm{B}_{2}$ & 2.4 & 8 & 1.8 & 7.8 & - & - & 0.6 & 0.2 & - & - \\
\hline $\mathrm{B}_{3}$ & 7.27 & 8.98 & 6.4 & 8.9 & 0.1 & - & 0.7 & 0.08 & 0.07 & - \\
\hline $\mathrm{B}_{4}$ & 3.1 & 9.3 & 2.3 & 7.4 & - & 1.3 & 0.8 & 0.6 & - & - \\
\hline $\mathrm{B}_{5}$ & 1.8 & 2.5 & 1.6 & 2.4 & 0.2 & - & - & 0.1 & - & - \\
\hline $\mathrm{B}_{6}$ & 3.7 & 2 & 3.0 & 1.8 & - & 0.2 & 0.7 & - & - & - \\
\hline $\mathrm{B}_{7}$ & 1.77 & 4.5 & 1.7 & 3.3 & 0.07 & - & - & 1.2 & - & - \\
\hline $\mathrm{B}_{8}$ & 4.8 & 4.6 & 4.8 & 3.1 & - & - & - & 1.5 & - & - \\
\hline $\mathrm{B}_{9}$ & 1.14 & 8.2 & 0.8 & 6.8 & - & - & 0.3 & 0.2 & 0.04 & - \\
\hline $\mathrm{B}_{10}$ & 4.4 & 4.6 & 3.5 & 4.6 & 0.3 & - & 0.6 & - & - & - \\
\hline $\mathrm{B}_{11}$ & 3.4 & 6.02 & 3.0 & 6.0 & - & - & 0.4 & - & - & 0.02 \\
\hline $\mathrm{B}_{12}$ & 4.1 & 4.5 & 3.8 & 4.5 & - & - & 0.3 & - & - & - \\
\hline The mass of weeds, $t / h a$ & 42.5 & 81.02 & 36.7 & 71.7 & 0.77 & 1.5 & 4.9 & 7.8 & 0.13 & 0.02 \\
\hline Participation, \% & 100 & 100 & 86.35 & 88.50 & 1.81 & 1.86 & 11.53 & 9.62 & 0.31 & 0.02 \\
\hline
\end{tabular}

Tab. 7. The influence of soil tillage system effects on crop production of soybeans, ARDS Turda, 2013

\begin{tabular}{ccccc}
\hline The factor & Yield, $\mathrm{kg} / \mathrm{ha}$ & Yield, $\%$ & Differences, $\pm \mathrm{kg} / \mathrm{ha}$ & Semnification \\
\hline $\mathrm{A}_{1}$ (- conventional with plowing) & 1474 & 100.0 & 0.00 & Mt. \\
\hline $\mathrm{A}_{2}$ (minimum tillage with chisel) & 1460 & 99.0 & -14 & - \\
\hline
\end{tabular}

DL5\%=138 kg/ha; DL1\%=185kg/ha; DL0.1\%=244 kg/ha

Tab. 8. The influence of herbicides on production variation at soy culture, ARDS Turda, 2013

\begin{tabular}{ccccc}
\hline Variant & Yield, $\mathrm{kg} / \mathrm{ha}$ & Yield, $\%$ & Diferences, $\pm \mathrm{kg} / \mathrm{ha}$ & Semnification \\
\hline $\mathrm{B}_{1}$ & 354 & 100.0 & $\mathrm{f} 0.0$ & Mt. \\
\hline $\mathrm{B}_{2}$ & 1553 & 439.4 & 1200 & $* * *$ \\
\hline $\mathrm{B}_{3}$ & 969 & 274.2 & 616 & $* *$ \\
\hline $\mathrm{B}_{4}$ & 1654 & 468.0 & 1301 & $* * *$ \\
\hline $\mathrm{B}_{5}$ & 1632 & 461.7 & 1279 & $* * *$ \\
\hline $\mathrm{B}_{6}$ & 1744 & 493.6 & 1391 & $* * *$ \\
\hline $\mathrm{B}_{7}$ & 1822 & 515.3 & 1468 & $* * *$ \\
\hline $\mathrm{B}_{8}$ & 2154 & 609.2 & 1800 & $* * *$ \\
\hline $\mathrm{B}_{9}$ & 1741 & 492.4 & 1387 & $* * *$ \\
\hline $\mathrm{B}_{10}$ & 1460 & 413.1 & 1107 & $* * *$ \\
\hline $\mathrm{B}_{11}$ & 1397 & 395.2 & 1043 & $* * *$ \\
\hline $\mathrm{B}_{12}$ & 1123 & 317.6 & 769 & $* *$ \\
\hline
\end{tabular}

DL5\%=442 kg/ha; DL1\%=594kg/ha; DL0.1\%=786 kg/ha 
Tab. 9. Influence of herbicide $x$ variant of system work the soil at cultivation of soybeans, ARDS Turda, 2013

\begin{tabular}{|c|c|c|c|c|}
\hline The factor & Yield, kg/ha & Yield, \% & $\begin{array}{c}\text { Differences, } \pm \mathrm{kg} / \\
\text { ha }\end{array}$ & Semnification \\
\hline $\mathrm{B}_{1} \mathrm{~A}_{1}$ (untreated) & 338 & 100.0 & 0.00 & Mt. \\
\hline $\mathrm{B}_{2} \mathrm{~A}_{1}$ (2 treatments) & 1696 & 501.4 & 1358 & $* * *$ \\
\hline $\mathrm{B}_{3} \mathrm{~A}_{1}$ (2 treatments) & 955 & 282.3 & 617 & $*$ \\
\hline $\mathrm{B}_{4} \mathrm{~A}_{1}$ (2 treatments) & 1825 & 539.6 & 1487 & $* * *$ \\
\hline $\mathrm{B}_{5} \mathrm{~A}_{1}$ (2 treatments) & 1681 & 497.0 & 1343 & $* * *$ \\
\hline $\mathrm{B}_{6} \mathrm{~A}_{1}$ (2 treatments) & 1798 & 531.4 & 1459 & $* * *$ \\
\hline $\mathrm{B}_{7} \mathrm{~A}_{1}$ (2 treatments) & 1810 & 535.2 & 1472 & $* * *$ \\
\hline $\mathrm{B}_{8} \mathrm{~A}_{1}$ ( 3 treatments) & 2083 & 615.7 & 1744 & $* * *$ \\
\hline $\mathrm{B}_{9} \mathrm{~A}_{1}$ ( 3 treatments) & 1780 & 526.2 & 1441 & $* * *$ \\
\hline $\mathrm{B}_{10} \mathrm{~A}_{1}$ (2 treatments) & 1188 & 351.1 & 849 & $* *$ \\
\hline $\mathrm{B}_{11} \mathrm{~A}_{1}$ ( 3 treatments) & 1183 & 349.8 & 845 & $* *$ \\
\hline $\mathrm{B}_{12} \mathrm{~A}_{1}$ (2 treatments) & 1353 & 399.9 & 1014 & $* * *$ \\
\hline $\mathrm{B}_{1} \mathrm{~A}_{2}$ (untreated) & 368 & 100.0 & 0.00 & Mt. \\
\hline $\mathrm{B}_{2} \mathrm{~A}_{2}(2$ treatments $)$ & 1410 & 382.4 & 1042 & $* * *$ \\
\hline $\mathrm{B}_{3} \mathrm{~A}_{2}(2$ treatments $)$ & 983 & 266.6 & 615 & $*$ \\
\hline $\mathrm{B}_{4} \mathrm{~A}_{2}$ (2 treatments) & 1483 & 402.2 & 1115 & $* * *$ \\
\hline $\mathrm{B}_{5} \mathrm{~A}_{2}$ (2 treatments) & 1583 & 429.3 & 1214 & $* * *$ \\
\hline $\mathrm{B}_{6} \mathrm{~A}_{2}$ (2 treatments) & 1692 & 458.8 & 1323 & $* * *$ \\
\hline $\mathrm{B}_{7} \mathrm{~A}_{2}(2$ treatments $)$ & 1833 & 497.2 & 1465 & $* * *$ \\
\hline $\mathrm{B}_{8} \mathrm{~A}_{2}$ ( 3 treatments) & 2225 & 603.3 & 1856 & $* * *$ \\
\hline $\mathrm{B}_{9} \mathrm{~A}_{2}$ ( 3 treatments ) & 1701 & 461.4 & 1333 & $* * *$ \\
\hline $\mathrm{B}_{10} \mathrm{~A}_{2}$ (2 treatments) & 1733 & 470.0 & 1365 & $* * *$ \\
\hline $\mathrm{B}_{11} \mathrm{~A}_{2}$ ( 3 treatments) & 1611 & 436.7 & 1242 & $* * *$ \\
\hline $\mathrm{B}_{12} \mathrm{~A}_{2}$ (2 treatments) & 893 & 242.2 & 525 & - \\
\hline
\end{tabular}

DL5\%=557 kg/ha; DL1\%=747kg/ha; DL0.1\%=987 kg/ha

\section{CONCLUSION}

Average yield obtained in soybean culture in the system with minimum tillage (version with chisel) is $1460 \mathrm{~kg} / \mathrm{ha}$, very similar to the conventional system yields (plowghing) which was $1474 \mathrm{~kg} / \mathrm{ha}$, an insignificant difference of$14 \mathrm{~kg} / \mathrm{ha}$. In these circumstances, we find that the work of the soil does not have significant influence on yields obtained statistically ensured the cultivation of soybeans.

As a result of the calculations performed on the degree of weeding in the two systems of cultivation of soybean, SC and MT, weeds DA and MA had the highest percentage of participation. The lack of rains in the spring resulted in the spread of appeared soybean crop infestation and overgrown with weeds, herbicide effect is diminished. Due to the grew of Xanthium strumarium spaced out, after all the treatments applied experience with soy, weeds grew again both in the version with MT and in SC, actually found as a result of hight weeds measurements made before harvest soybean seeds.

The number and mass of weed control untreated version significantly reduce soybean yields (338 kg/ha in SC and $368 \mathrm{~kg} / \mathrm{ha}$ in the MT). 
The best weed control results are obtained in the $\mathrm{B}_{6}$ (Sencor WG 70 in rates $0.4 \mathrm{~kg} \backslash /$ ha apply ppi; Basagran Forte + Agil in $2.5 \mathrm{l} /$ ha in rates 1.0 l/ha with post-emergent I application) and the $\mathrm{B}_{7}$ (Guardian $\backslash$ Acetogan + Sencor $2.2 \mathrm{l} \backslash /$ ha +0.4 $\mathrm{kg} \backslash /$ ha with soil incorporation preem; Pulsar + Fusilade $1.2 \mathrm{l} \backslash /$ ha $+1.5 \mathrm{l} \backslash /$ ha apply post I).

Acknowledgments: This paper was published under the frame of European Social Fund, Human Resources Development Operational Programme 2007-2013, projectno. POSDRU/159/1.5/S/132765.

\section{REFERENCES}

1. Ardelean, M., M. Cordea, R. Sestras (2010). Tehnică experimentală. Ed. AcademicPres, Cluj-Napoca.

2. Berca, M. (2004). Managementul integrat al buruienilor. Ed. Ceres, București, p. 277.

3. Bucur, D., G. Jităreanu, C. Ailincăi (2011). Effects of longterm soil and crop management on the yield and on the fertility of eroded soil. Journal of Food, Agriculture \& Environment Vol.9 (2): 207-209.

4. Fabrizzi, K. P., F. O. Garcia, J. L. Costa, L. I. Picone (2005). Soil water dynamics, physical properties and corn and wheat responses to minimum and no-tillage systems in the southern Pampas of Argentina. Soil \& Tillage Research 81: 57-69.
5. Gus,, P., S. Cernea, T. Rusu, I. Bogdan (2004). Sisteme de semănat, fertilizat si întreținere a culturilor. Editura Risoprint, Cluj-Napoca, p. 220.

6. Ionescu, N. E. (2000). Combaterea buruienilor și protecția mediului în cultura cerealelor și aplantelor tehnice. Ed. SCNelmaco Impex SRL București, p. 151-152.

7. Moraru, P. I., T. Rusu, M. L. Sopterean (2010). Soil Tillage Conservaton and its Effect on Erosion Control, Water Management and Carbon Sequestration. In ProEnvironment / ProMediu no. 3: 359 - 366.

8. Moraru, P. I., T. Rusu (2013). Effect of Different Tillage Systems on Soil Properties and Production on Wheat, Maize and Soybean Crop. World Academy of Science, Engineering and Technology, Paris, France, Issue 83: 162165.

9. Muntean, L.S., M. Axinte, I. Borcean, Gh. Roman (1995). Fitotehnie, EDP, București.

10. Rusu, T. (2001). The influence of Minimum Soil Tillage upon the soil, yield and efficiency. PhD Thesis, University of Agricultural Sciences and Veterinary Medicine of ClujNapoca.

11. Rusu, T., I. Bogdan, A. I. Pop (2012). Îndrumător de lucrări practice la Agrotehnicǎ. Ed. Grinta, Cluj-Napoca.

12. Rusu, T., P. I. Moraru, C. L. Coste, H. Cacovean, F. Chețan, C. Chețan. (2014) Impact of climate change on climatic indicators in Transylvanian Plain, Romania. Journal of Food, Agriculture \& Environment Vol. 12 (1): 469-473.

13. Scurtu, I. (2001). Economia și tehnologia culturilor agricole. Ed. Independența economică, Pitești, p. 231-236. 